\title{
Multiple-Draft/Multiple-Party Feedback Practices in an EFL Tertiary Writing Course: Teachers' and Students' Perspectives
}

\author{
Ha Thi Nguyen ${ }^{1} \&$ Anna Filipi $^{2}$ \\ ${ }^{1}$ Faculty of Education, Monash University, Melbourne, Australia \\ Correspondence: Ha Thi Nguyen, Faculty of Education, Monash University, 19 Ancora Imparo Way, Clayton \\ Campus, Victoria 3800, Australia. Tel: 61-416-545-524. E-mail: ha.nguyen1@monash.edu
}

Received: March 12, 2018

Accepted: May 11, $2018 \quad$ Online Published: July 6, 2018

doi:10.5539/ies.v11n8p1

URL: https://doi.org/10.5539/ies.v11n8p1

\begin{abstract}
Based on various sources of data collection for a qualitative research project, the study reported in this paper set out to examine four teachers' and sixteen students' perceptions of a multiple-draft/multiple-party feedback approach to English as a Foreign Language (EFL) student writing. This approach had been implemented as a trial in a tertiary setting in Vietnam. Three sources of feedback at three phases were provided. These included (1) peer/group written and oral feedback on the students' first drafts, (2) a teaching assistant's written and oral feedback on their second drafts and (3) the lecturer's written feedback on their final drafts. Content analysis of the data revealed that all participants valued this multiple feedback approach because of its practicality and the quality of the feedback which participants believed contributed to writing improvement. Based on the participants' reactions, the study highlights the potential of multiple-draft/multiple-party feedback practices for improving English language writing in a tertiary context.
\end{abstract}

Keywords: assessment for learning, EFL writing, higher education, L2 writing, multiple-draft and multiple-party feedback, teachers' and learners' perspectives

\section{Introduction}

There is little doubt that providing feedback on student writing is regarded as one of the most important tasks for English language teachers (K. Hyland, 2003). However, in spite of teachers' concerted efforts to give feedback, students continue to make the same errors and depend on the teacher to provide feedback (Lee, 2011b). One possible reason is the quality and delivery of the feedback. For example, a common practice in the Asian context is for teachers to highlight errors and allocate marks to students' final writing products (Lee, 2011b, 2011d). Such a practice can overwhelmingly result in students keeping a greater eye on grades or scores and less on teachers' comments as Black, Harrison, Lee, Marshall, and Wiliam (2007) and Lee (2011b, 2011d) contend. Accordingly, opportunities to focus on the learning process are lost. In other words, assessment for learning (AFL) is not effectively activated in such feedback practices.

In Vietnam, teaching and learning about writing are normally believed to be challenging for both teachers and learners since they make "a lot of demands on any teacher and learner of EFL" (H. H. T. Nguyen, 2009, p. 61). Consequently, research has focused on examining teachers' and learners' motivation, attitudes and perceptions towards teaching and learning EFL writing in Vietnam (for example, in studies by T. M. H. Nguyen \& Hudson, 2010; Tran, 2007) rather than on the application of AFL in feedback practices in general and/or in multiple-draft feedback practices in particular, the research interest of the study reported in this paper. The study, which is part of a larger project that described practice, then developed and trialled an alternative assessment feedback approach (see T. H. Nguyen, 2016b), attempts to foreground the ten principles of AFL introduced by the Assessment Reform Group (ARG) in 2002. It will do this through (1) its evaluation of a trialled multiple-draft/multiple-party feedback (Filipi, 2017) approach and (2) its analysis of the teachers' and students' perceptions and reactions to the approach in two classes of an EFL tertiary writing course in Vietnam. Specifically, the study seeks to answer the following research questions:

1) In what ways does the trialled multiple-draft/multiple-party feedback approach in an EFL tertiary writing course in Vietnam align with the identified principles of AFL?

2) What are the teachers' and students' perceptions about the trialled multiple-draft/multiple-party feedback 
approach?

We start by presenting an overview of the concept of AFL and a brief summary of previous research with regard to teachers' and learners' perceptions of feedback practices in English writing classes before turning to the details about the study.

\section{Previous Research}

\subsection{The Concept of AFL and Its Links to Feedback}

The Assessment Reform Group (ARG) (2002, p. 2) defines assessment for learning (AFL) as: "the process of seeking and interpreting evidence for use by learners and their teachers, to identify where the learners are in their learning, where they need to go to and how best to get there". It has developed a list of ten principles which we believe are workable in a classroom context from the perspectives of both teachers and learners. These principles can inform the development of tasks that promote AFL so that they occur as ongoing tasks in the classroom rather than as separate tasks that are tacked on or additional to them (Black et al., 2007). The ten principles characterize AFL as:

1) being part of effective planning

2) focusing on how students learn

3) being central to classroom practice

4) being a key professional skill

5) being sensitive and constructive

6) fostering motivation

7) promoting understanding of goals and criteria

8) helping learners know how to improve

9) developing the capacity for self-assessment

10) recognising all educational achievement

A number of the above principles $(2,5,6,7,8,9$ and 10) refer to the centrality of feedback and to how it contributes to raising learners' achievement (Swaffield, 2008). Indeed, various scholars (e.g., Black et al., 2007; Brookhart, 2008; Lee, 2011a; Swaffield, 2008) maintain that there is a close and supportive relationship between quality feedback which should be both "descriptive and diagnostic" (Lee, 2017, p. 16) and AFL. For example, Swaffield (2008, p. 70) maintains that: "feedback is a direct way of making learning explicit, and it has a large part to play in helping pupils become more autonomous learners and supporting their development of agency" while Brookhart (2008) maintains that good feedback has the potential to strengthen AFL by stimulating students' cognition and motivation.

The role of feedback in AFL contributes significantly to the current investigation on feedback practices with its specific focus on how to stimulate the implementation of AFL in EFL tertiary writing classes. As noted in the definition of AFL, both teachers and learners play significant roles in the process of ongoing learning and assessment. Therefore, in order to understand how feedback can be built on to have a significant role in improvement, we first need to understand from previous research how teachers and students have reacted to various feedback practices.

\subsection{Previous Investigations about Teachers' and Students' Perceptions about Feedback Practices}

\subsubsection{Teachers' Perceptions}

Research on teacher feedback on writing in English as a Second Language (ESL) and EFL classrooms reveals that teachers believe the purposes of feedback are to: (1) help students increase their language awareness as well as their writing skills (Evans, Hartshorn, \& Tuioti, 2010; Lee, 2011a, 2011d); (2) meet students' demands and expectations (Evans et al., 2010; Ferris, 2014; Lee, 2008; Montgomery \& Baker, 2007); (3) meet the requirements of their schools and/or programs (Evans et al., 2010; Lee, 2008, 2011d); and (4) develop learners' motivation (Evans et al., 2010; Lee, 2011d). Research has also been conducted on the patterns of feedback in written and/or oral teacher feedback on different drafts in: ESL contexts (Ferris, 2006, 2014; Paulus, 1999), EFL secondary settings (Lee, 2011a, 2011c, 2011d) and Turkish (Ekşi, 2012) and Chinese tertiary contexts (Yang, Badger, \& Yu, 2006). While most of these previous studies have focused on the purposes of feedback in English writing classes in general and on the benefits of teacher and peer feedback in developing students' writing through a multi-draft feedback approach in ESL contexts or EFL secondary schools in particular, only a very small number of studies 
(e.g., Ekşi, 2012 and Yang et al., 2006) have investigated the multiple-draft feedback approach in EFL higher education. The current study seeks to extend the literature on teachers' perceptions about various sources of feedback in a specific EFL tertiary writing course in Vietnam.

\subsubsection{Students' Perceptions}

In studies of students' perceptions, prior research has examined students' opinions about teacher and peer feedback in English writing classes. A substantial number of studies indicates that ESL/EFL students favour teacher feedback provided either directly or indirectly. For example, students believe that direct feedback/correction is helpful for effective revision (Chandler, 2003; F. Hyland, 2003, 2011) and time efficient both for students and teachers in revising and correcting drafts (Chandler, 2003). Teachers' indirect correction is also valued by students for its perceived positive impact on their learning; for example, in developing their language acquisition (Chandler, 2003; Leki, 2006) and in enhancing their learning autonomy (F. Hyland, 2011).

English language learners have also been shown to value peer feedback for the following reasons. First, it can strengthen their autonomy in multiple-draft feedback practices (Ekşi, 2012; Yang et al., 2006). Second, engaging in peer feedback by reviewing their writing helps to develop their vocabulary and understanding of sentence structure (Ekşi, 2012; Sato, 2013; Yang et al., 2006; Zhao, 2014). Third, opportunities for peer interaction help students establish mutual understanding by limiting misinterpretation or miscommunication, and in so doing they believe they can develop their speaking skills (Sato, 2013; Yang et al., 2006; Yu \& Lee, 2014; Zhao, 2014). Thus, peer feedback is believed to benefit students' language acquisition.

In summary, while this brief review illustrates that students appreciate both teacher and peer feedback, there appears to have been less attention paid to systematic classroom approaches that combine both multiple-party and multiple-draft phases, particularly in the Vietnamese context. This suggests a fruitful area for research.

\section{The Study}

\subsection{Context and Participants}

The University of Success (a pseudonym) is a state university whose primary objective is the professional development of teachers for all educational levels in Vietnam. One of the major objectives of the Faculty of English in this university is to educate English majors in teaching English as a Foreign Language (TEFL) as part of a four-year Bachelor of Arts (BA) program. The research reported in this paper was focused on the third-year English writing program in which there were fifteen class hours dedicated to writing skills per semester. Each class lasted fifty minutes. In the first semester of this course, a key focus of learning was to be able to produce a written task of at least 150 words that summarised the information illustrated in a table, a chart or a process - a task similar to Writing Task 1 in the IELTS academic writing module. In the second semester, students were taught to produce argumentative and discursive tasks of at least 250 words - similar to Writing Task 2 in the IELTS academic writing.

The participants, from two writing classes, included sixteen third-year English majors, two lecturers and two teaching assistants. Pseudonyms were used for all the participants to ensure ethical research practices. The students' English language proficiency levels fell between intermediate and upper-intermediate level, equivalent to B1 and B2 levels in the Common European Framework of Reference for Languages (CEFR) (Council of Europe, 2001). The following tables summarise the profiles of the student and teacher participants.

Table 1. Profiles of the student participants

\begin{tabular}{lcccc}
\hline Order & Name & Class & Age & Years of learning English \\
\hline 1 & Bich & A & 20 & 10 \\
2 & Dieu & A & 20 & 10 \\
3 & Duong & A & 20 & 10 \\
4 & Ha & B & 20 & 10 \\
5 & Hai & B & 20 & 10 \\
6 & Hang & B & 20 & 10 \\
7 & Hong & B & 20 & 10 \\
8 & Lan & A & 22 & 11 \\
9 & Le & A & 20 & 10 \\
10 & Lien & B & 23 & 12 \\
11 & Minh & A & 20 & 10 \\
\hline
\end{tabular}




\begin{tabular}{lclll}
\hline 12 & Ngoc & A & 20 & 10 \\
13 & Phan & A & 20 & 10 \\
14 & Thuy & B & 20 & 10 \\
15 & Tu & B & 20 & 10 \\
16 & Xuan & B & 20 & 10 \\
\hline
\end{tabular}

Table 2. Profiles of teacher participants

\begin{tabular}{lccccc}
\hline Title and Name & Class & Age & $\begin{array}{c}\text { Years of teaching } \\
\text { English at tertiary level } \\
\text { (up to 2013) }\end{array}$ & $\begin{array}{c}\text { Years of teaching English } \\
\text { writing skills } \\
\text { (up to 2013) }\end{array}$ \\
\hline 1. Lecturer Yen & A & 25 & 04 & 02 & Mualifications in \\
TEFL & 10 & 0 & Masters \\
2. Lecturer Oanh & B & 33 & 01 & 01 & 0 \\
3. Teaching assistant Thu & A & 22 & B & 01 & Bachelor \\
4. Teaching assistant Hoa & B & 23 & & 0 & 0 \\
\hline
\end{tabular}

\subsection{Data Collection and Analysis}

Data for this study was derived from twenty individually audio-recorded, semi-structured interviews of 30-45minute duration, classroom observations of two 50-minute writing sessions in each class, and five students' writing samples from each class. Class observation data was gathered in week 6 and week 9 of the second semester. In these writing classes students sat in groups of four to provide written feedback on the first drafts written by their peers in a different group. Interview and document data was collected at the end of the second semester. Interview questions for student participants differed slightly from those for teacher participants because of their different roles in the writing classes (see Appendix A). Responses to the interview questions were given in Vietnamese by the participants and then translated into English by the first author.

In this qualitative research, content analysis (Lichtman, 2014) was adopted as the primary method for data interpretation and analysis using the "Three Cs strategy" of coding, categorizing and conceptualizing to seek major themes from the interview and observation data. The three-step strategy was conducted in the following ways. First, different symbols for coding purposes were assigned to each participant group. Second, all the data was interpreted, summarized and categorized into sub-themes and major recurring themes across the data sample to address the research questions. Third, the first author's own reflexivity in her role as a teacher of English writing skills in Vietnam was used for interpretation and analysis. Such an approach accords with Patton (2002) who stresses that the researcher should pay attention to reflexivity to strengthen the credibility of the findings.

In analysing and interpreting the data, a "thick" description (Denzin, 1989) was conducted to enable a "thick" or deeper interpretation of the data. In order to achieve the former, actual quotations from the participants, researcher notes from class observations, examples from students' writing drafts and peer and teacher feedback were used to formulate findings. In providing a thick interpretation of the data, analysis of the similarities and differences between the teachers' and students' perspectives about the multiple-feedback approach was made with reference to the ten principles of AFL discussed above and by drawing on the literature on feedback practices in L2 writing classes.

\section{Results and Discussion}

4.1 How the Multiple-Draft/Multiple-Party Feedback Approach in Two EFL Tertiary Writing Classes in Vietnam Aligns with the AFL Principles

\subsubsection{The Multiple-Draft/Multiple-Party Feedback Approach}

The development of the multiple-draft/multiple-party feedback approach to EFL students' writing was a major component of a doctoral research project which was piloted in the second semester of the third-year writing program in an undergraduate course in TEFL at the University of Success, Vietnam (see T. H. Nguyen, 2016b). Description about this trialled approach is illustrated in Figure 1, followed by an analysis and discussion about the ways it links to the AFL principles. 


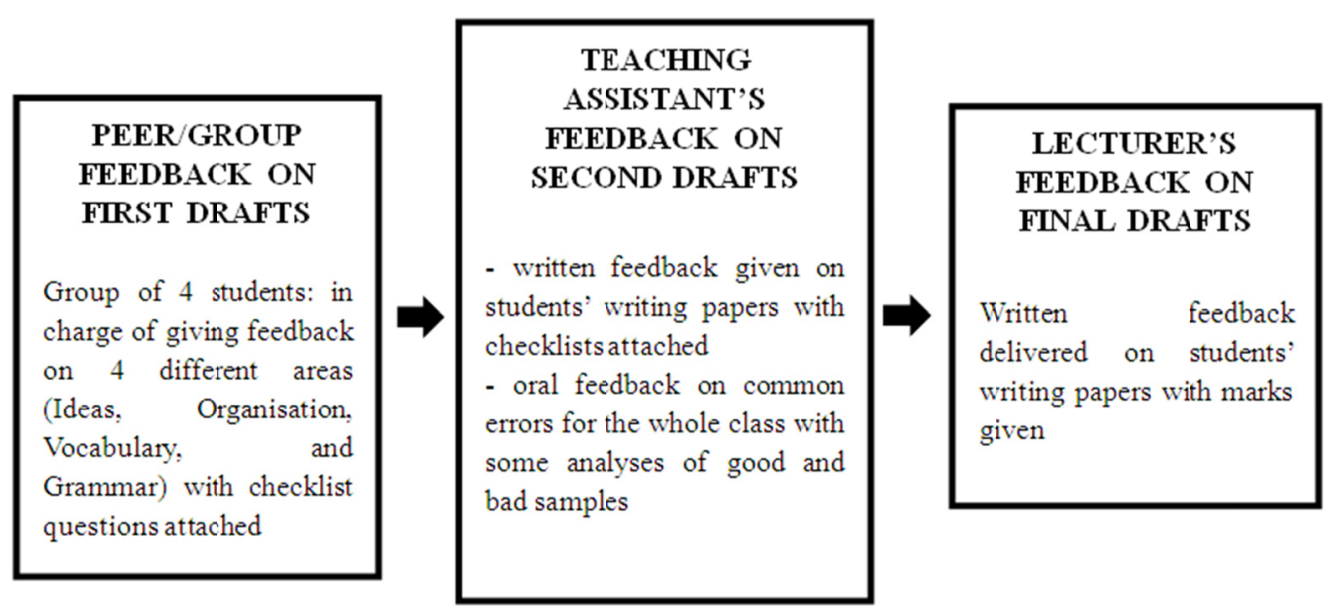

Figure 1. Multiple-draft/ multiple-party feedback approach in an EFL tertiary writing course

As can be seen in the above figure, the trialled feedback approach is based on three student drafting phases: (1) the first draft for which students receive peer/group written and oral feedback, (2) the second draft for which students receive the teaching assistant's written and oral feedback, and (3) the third and final draft for which students receive the lecturer's written feedback. The process of revising drafts helped to enhance students' self-assessment, which aligns both with the ninth principle of AFL (ARG, 2002) and with research that suggests that opportunities for self-editing are provided to the learners through a multi-draft process (e.g., Bitchener \& Ferris, 2012; Brookhart, 2008; Lee, 2011a, 2011c, 2011d). Importantly, the activity of revising drafts emphasizes a learner-centred, process approach rather than a product approach; this aligns with the second and eighth principles of AFL (i.e. focusing on how students learn and helping learners know how to improve). Thus when students are in control of revising their writing, the potential for improvement is maximised since as Lee (2011d, p. 393) pointed out: "to ensure that assessment is used for formative purposes, it is crucial that students have the opportunity to work on the weaknesses identified by the teacher by revising a previous draft". In the next sections, we focus more explicitly on each of the drafting phases.

\subsubsection{First Drafts: Peer/Group Feedback}

In this first phase, students worked in groups of four and were given ten minutes to provide feedback on each student's drafts. Each member of a group (as nominated by the lecturer) was charged with providing feedback on one of the following criteria: ideas, organization, vocabulary or grammar in a given checklist developed by T. H. Nguyen, (2016 a, b) (see also Appendix B). In addition to written feedback, classroom observations uncovered that group members interacted with each other and with the teaching assistant and/or the lecturer during this peer feedback response activity. These interactions involved students discussing their thoughts about correction and sharing their comments. Interactions with the teaching assistants and the lecturers took place when the students sought assistance or clarification about the accuracy of their feedback, a recurring practice noted also by Hoa, the teaching assistant:

In the peer response activity, the students worked in a group for a fixed period of time in class and they did it seriously. For example, they spent time asking each other about error correction, and when they had received feedback from their friends, they also spent time asking their friends for clarification. Students sometimes asked me for confirmation of errors about which they were uncertain.

(Further supporting written document data for peer feedback can be seen in Appendix B.)

This specifically organized peer feedback activity phase in the writing classes involved all the learners in providing feedback. As a practice, it accords with the third principle of AFL that feedback should be central to classroom practice.

4.1.3 Second Drafts: Teaching Assistant's Feedback

As noted, there were two novice teachers in the roles of teaching assistants, Thu in Class A and Hoa in Class B. By participating in the second phase of this trialled feedback approach, they provided both oral and written feedback on the students' second drafts. 
Analysis of the ten samples of student writing in both classes revealed that the teaching assistants delivered feedback on all four criteria in the checklist by ticking and providing additional written feedback in the relevant column for each criterion (see Appendix B). Consistent with Lee's (2017) claim that quality feedback needs to be both descriptive and diagnostic, the feedback provided both direct correction and detailed comments on each of the criteria in the checklist and pointed out where improvements were needed. In this respect, the teaching assistants were potentially enacting the eighth principle of AFL which facilitates learners in making improvements with teachers' constructive guidance. Hoa's statement illustrates this point:

When giving written feedback, I focused on errors in all four criteria in the checklist and noted common errors that most students had made. I even noted down serious mistakes that a few of the students had made to mention in the general oral feedback session.

In this phase, the teaching assistants also made notes for a subsequent whole class "clinic" that occurred directly after papers were returned to the students. They gave oral feedback on common errors against each of the criteria in the checklist by drawing on relevant examples from the student drafts. Some analysis of good or poor sample answers was also provided. Throughout the session, they asked learners for their input as demonstrated in the following:

Regarding oral feedback, I usually wrote some of the students'sentences on the board and asked the whole class to indicate errors and suggest ways to improve them. When their suggestions for correction were not similar to mine, I would suggest my own correction. (Thu)

These clinics provided an opportunity for the students to develop their critical thinking about error analysis and improvement because they were actively engaged through invited interaction to make suggestions and analyse errors. It allowed students to further enhance their language awareness and extend their experience of giving feedback during the first draft process. Therefore, the potential for three principles (7,8 and 9) of AFL were activated because students were able to more explicitly understand the criteria for assessment and the purpose and goals of their writing. This in turn enabled them to know how and where to improve, and at the same time, develop their capacity for self-assessment while reviewing by better understanding how to work with feedback received.

A further point about the importance of making feedback comprehensible by promoting understanding about goals and criteria (AFL principle 7) and providing feedback that is constructive (AFL principle 5) is the medium chosen for delivering it. The classroom observations indicated that the teaching assistants used their first language, Vietnamese, in giving their oral feedback. The choice of L1 in oral feedback delivery was reported to exert an immediate benefit to the participants. Lan, a student in Class A, stated that "the teaching assistant usually gave oral feedback in Vietnamese. In doing so, we could understand her feedback easily".

The support of L1 in the L2 setting in this study is in line with the literature about the role of the L1 in L2 learning and teaching (e.g., Filipi, 2018; Storch \& Aldosari, 2010). For instance, Storch and Aldosari (2010, p. 371) argue that using the L1 could give learners "timely assistance about word meaning" to ease L2 learning, while Filipi (2018) proposes that teacher language alternation practices are bound up with expectations that teachers have about what a student should understand in the respective languages. Switching to the L1 is therefore a practice that is launched to establish and facilitate understanding. The latter certainly seems to have relevance with respect to the teaching assistants' practices because they did not expect the students to have sufficient proficiency in English to understand the metalanguage necessary to explain grammatical errors. This finding certainly points to the need for further studies that examine language alternation and the distribution of each language in delivering feedback in an EFL tertiary context.

\subsubsection{Final Drafts: Lecturer's Feedback}

Lecturer written feedback is recorded in the last phase of the trialled feedback approach. The analysis has shown that the lecturers' written feedback focused on providing general comments in addition to allocating a final numerical mark on the students' final drafts. Analysis also showed that in addition to a total mark, the lecturers provided a numerical mark for each criterion; i.e. ideas, organization, vocabulary and grammatical range (see Appendix B). Research has shown that marks can help to confirm the writers' level and foster the students' motivation in their subsequent writing of papers (Ferris, 2006), promoting the sixth principle of AFL (fostering motivation).

Despite the common assumption that the final drafts were the best of the three drafts, the lecturers reported having to spend time giving further explicit comments and making indirect error correction on student writing. One reason given for the need to do this, was their belief that the students had neither the skill nor the experience to provide feedback. Oanh's statement is illustrative: 
Due to the students' limited capacity in providing feedback, the teaching assistants' and lecturers' commitment to feedback was more noticeable. It seemed that the students and teachers spent equal amounts of time giving feedback, but the latter's commitment in providing feedback was more than that of the former. Some errors in the mechanics of language were sometimes found in the final drafts.

The above suggests a need to better prepare students for effective peer assessment. It also points to the ways in which existing gaps in student language knowledge, provided by rich assessment processes, can be used to inform teaching.

So far, we have been discussing data (derived from the classroom observations, the student drafts and interview data) to highlight the alignment of each feedback phase with the principles of AFL. Next, we turn to the participants' perspectives by examining the interview data.

\subsection{Teachers' and Students' Perceptions of the Multiple-Draft/Multiple-Party Feedback Practices}

Analysis of the interview data showed that participants held shared views about three strengths of the multiple-draft/multiple-party feedback approach: quality of the feedback, perceived improvement in students' writing and students' active participation in the feedback approach. A recurring weakness that was reported was the participants' skepticism about the accuracy of peer feedback. Discussion begins with an examination of the three perceived strengths.

\subsubsection{Perceived Strengths}

* Quality of the feedback

Student participants appreciated the opportunity to receive three sources of feedback at three stages of their writing. Teacher participants expressed their satisfaction with the process of providing feedback on the students' second and final drafts which had been substantially revised by the students themselves after the peer review.

Ten student participants agreed with Duong's view below while three teacher participants agreed with Yen about feedback quality.

We were very interested in this approach because we could receive feedback for two drafts before writing the final draft to receive the lecturer's comments and marks. Another interesting thing was that there was the teaching assistant's feedback. (Student Duong)

I realised that this practice was totally new compared to previous feedback approaches. The teaching assistant worked very effectively in the second draft correction, so it was easier for me to give feedback on the final drafts. (Lecturer Yen)

The participants' reports about the quality of multiple-draft/multiple-party correction revealed that this practice activated the first, third and sixth principles of AFL: being part of effective planning, being central to classroom practice and fostering motivation. Notably, group feedback and the teaching assistant's oral feedback occurred during class time and did not disrupt the normal lesson. It involved effective planning for teaching and learning through: the specific staging of processes and planning of three separate phases, the organization and grouping of different participants, and provision of checklists and appropriate timing. Furthermore, the first draft feedback activity was learner-centred and afforded the students opportunities to participate actively in feedback practices, and to receive informed, valued and targeted feedback on more than one draft and from various sources. The latter concurs with the recommendations for best feedback practices put forward by Bitchener and Ferris (2012, p. 134) who suggest that instructors are generally believed to "have the required knowledge" and "sufficient training and experience to know what works best for individual learners". Similarly, the lecturers believed that the multiple-draft approach was an advantage for them since their task of providing feedback on the final drafts was considerably lessened as illustrated in Yen's statement above.

Additionally, findings about feedback quality in this feedback practice was documented in the perceived growth of the teacher's professional development which aligns with the fourth principle that characterizes AFL as being a key professional skill. In the words of Hoa, the teaching assistant:

I realised that I was more confident in providing feedback on the students' writing in this approach. Although I had to spend much time giving feedback, I felt happy in locating and correcting errors on the students' drafts. I think it was a time-consuming task, but it was really rewarding and effective.

Hoa's satisfaction with the process accords with the belief that in AFL "teachers come to enjoy their work more and to find it more satisfying because it resonates with their professional values" (Black et al., 2007, p.19).

The above findings about feedback quality in this multiple-draft/multiple-party feedback approach adds to the 
literature on the positive impacts of multiple-draft feedback in L2 writing (Ekşi, 2012; Ferris, 2014; Lee, 2011a, 2011c, 2011d; Paulus, 1999; Yang et al., 2006). This research highlights various patterns of teachers' feedback on different drafts in ESL contexts or in EFL secondary education. However, missing from this research is the EFL higher education context especially the Vietnamese one. As far as we are aware, only two empirical studies have proposed the application of a two-pronged approach to feedback: paired peer feedback on first draft correction followed by teachers' feedback on the final drafts (Ekşi, 2012; Paulus, 1999). The current study extends this to a three-pronged feedback approach (Filipi, 2017) and supports Bitchener and Ferris' (2012) recommendation about the need for and usefulness of various instructors' feedback in L2 writing by extending it to include teacher assistant feedback. It thus draws attention to the fact that multiple-party feedback approaches have been under-explored in L2 writing classrooms.

\section{* Students' writing improvement}

The next strength of the multiple-draft/multiple-party feedback approach identified by the participants was improvement in the students' writing. As seen in the table below, a greater number of participants expressed the view that language use (such as vocabulary and grammatical structures) improved while fewer participants believed that improvements to content (including organization, and generating, expressing and developing ideas) accrued.

Table 3. Participants' perspectives about the students' writing improvement

\begin{tabular}{|c|c|c|c|c|}
\hline Aspects of improvement & Students & Total & Teachers & Total \\
\hline $\begin{array}{l}\text { Generating, expressing and/or developing } \\
\text { ideas }\end{array}$ & Ha, Hai, Hang, Hong, Lan, Le, Minh, Ngoc, Tu & $9 / 16$ & Oanh & $1 / 4$ \\
\hline Organization & Bich, Dieu, Hai, Le, Ngoc, Thuy, Xuan & $7 / 16$ & Oanh & $1 / 4$ \\
\hline Vocabulary & $\begin{array}{l}\text { Dieu, Duong, Hai, Hang, Lan, Lien, Minh, Ngoc, Phan, } \\
\text { Tu, Xuan }\end{array}$ & $11 / 16$ & $\begin{array}{l}\text { Yen, Oanh, Hoa, } \\
\text { Thu }\end{array}$ & $4 / 4$ \\
\hline Grammatical structures & Dieu, Ha, Hang, Hong, Lien, Ngoc, Tu, Xuan & $8 / 16$ & $\begin{array}{l}\text { Yen, Oanh, Hoa, } \\
\text { Thu }\end{array}$ & $4 / 4$ \\
\hline
\end{tabular}

The last principle of AFL speaks to the need to "recognize the full range of achievements" (ARG, 2002, p.2). Within the writing task in the course under study, this includes both the mechanics of writing and effective ideas for development of topic. More than half of student participants believed that they achieved progress in both control of language and content in their writing. The following excerpt illustrates the students' perspectives on various areas in which they perceived themselves to have improved.

I realise that I've had more ideas for my writing. Before, I had often been stuck in developing my ideas, so it took a long time to complete a paper. Also, I've made some progress in my vocabulary such as word use, and in combining simple sentences into compound, complex ones. I have been aware of using academic words and of avoiding informal words in my writing. I have made more progress than in previous semesters. (Hang)

Further examples about the students' advances in control of language relative to the development of main ideas to strengthen their arguments are illustrated in Appendix C.

All the teacher participants believed that the students had improved their capacity to use academic vocabulary and sentence structures. The following is one typical statement to illustrate:

I realised that in this semester the students have made much more progress in language use, especially in the essays about advantages/disadvantages and about problems/solutions. They could use a variety of academic words and sentence structures such as inversion. The students used many interesting words as well. (Lecturer Yen)

However, only the lecturer Oanh reported the students' progress in developing ideas and organization of the essay:

The students have made some progress in the following aspects. First, they were aware about the specific audience of their writing, so they were always careful in planning their writing such as how to write, how to develop an idea. Second, the students have made so much progress in organizing an essay. Almost 100\% of the students in my class were aware that they had to produce a complete essay (including the introduction, the body and the conclusion in 40 minutes). They were also aware about how their writing papers were assessed such as how well they addressed the task and how well they expressed their ideas. Their 
vocabulary and grammar were also better than before.

These findings are consistent with prior research on the effects of multiple draft correction in L2 writing (Ferris, 2006; Paulus, 1999) which report that students made more gains in their language accuracy than in content. On a related point, Black et al. (2007, p.19) argued that in formative assessment "the changes can be made step by step - a big "leap in the dark" is not necessary", so the above aspects of the students' improvements were an encouraging sign for the efficacy of the multiple-draft/multiple-party feedback practices in student writing development that could be enhanced over time.

\section{- Students' engagement in feedback practices}

The final perceived strength of the multiple-draft/multiple-party feedback was the students' active participation in this process, evident in their engagement during class and the development of their learner autonomy.

Nine students and all four teachers expressed similar viewpoints in the interviews about students taking the task seriously and their interest in the feedback activities. The following excerpts are representative of the students' perceptions:

In my group, we were so serious in doing group feedback. Every member was aware of the need to give feedback on both strengths and weaknesses to their peers. We took it seriously not because of the teachers' request, but because we all thought that the others were giving serious feedback on our drafts, so we should do it as well as possible. (Phan)

The students were very serious in doing group feedback. They even brought materials and dictionaries with them to refer to when giving feedback to their peers. (Hai)

Group feedback was very effective because it created a comfortable atmosphere in writing classes. (Dieu)

Student perceptions also suggest that group feedback helped to increase their sense of comfort and respect for their peers during their engagement which in turn promoted the students' serious participation in this activity. The result supports the principle of creating "a comfortable environment for students" for effective peer feedback as suggested by K. Hyland (2003).

The students' opinions about their active engagement in this multiple-draft feedback practice were consistent with the teacher participants' perspectives. All of the teacher participants praised the students' positive attitudes. For example, Hoa said:

In this feedback practice, the students understood the criteria about the qualities of a well written paper and about how to give feedback on their peers' writing. They were also aware of what they were doing and what they could improve after being involved in group feedback, so they were serious in participating in this activity. This contrasts with the previous semester when the students had been required to produce only one draft; they didn't know how to improve their writing upon receiving a mark. They didn't make any effort to revise their writing. In this practice, the students were better motivated than before... They wanted to know about the reasons for their errors, and they asked immediately about what to do for improvement. In general, they were very active in asking questions.

Additionally, students' active participation in this feedback approach could also be found in their own awareness of the need to develop their autonomy to improve their writing. For instance, Bich said:

When revising my drafts, I myself found a proper way to improve my writing. Sometimes I asked for help from my friends based on the teachers' suggestions to find out the most appropriate way to improve my writing.

Hong spoke of her awareness of cultivating her autonomy:

Before I didn't have a habit of noting down my strengths and weaknesses when I received feedback. But in this feedback practice, I pushed myself to do this, to find out what was useful for me later. This was the first time I had done this task.

In summary, the participants' perceptions about the strengths and pedagogical benefits of the multiple-draft/multiple-party feedback showed how they were enacting the AFL principles as listed above with particular reference to principles 1, 2 and 8 (i.e. being part of effective planning, focusing on how students learn and helping learners know how to improve), highlighting the benefits of interaction and the diagnostic nature of the feedback so that the learners could act on advice for their writing improvement.

4.2.2 Limitations

Participants highlighted one weakness of the multiple-draft/multiple-party feedback approach: concerns about the 
accuracy and lack of confidence in their peers' feedback. Ten students and three teachers expressed this view. Lan's comment illustrates:

It was clear that in peer responses some didn't know how to correct errors despite the guidelines in the checklist. We didn't trust much of the group feedback because we were at the same level and couldn't be sure that our friends were better than us. We still waited for the teaching assistant's feedback.

Students also maintained that their own limited knowledge impacted negatively on the effectiveness of peer feedback which may have led to the students' distrust of their peers' feedback.

Group feedback was only partially effective because our knowledge about writing was not good enough. Many of us were not able to give feedback on some items in the criteria, especially ideas and vocabulary. I could only give feedback on simple vocabulary errors; there were errors which I couldn't locate or suggest for improvement. (Le)

The teacher participants' views accorded with those of the students. Oanh, for example, confirmed the students' lack of confidence in their peers' feedback:

I realised that there were some students who were not confident in giving feedback on their friends' writing and some students who didn't trust their friends'feedback. Therefore, there was some feedback focusing on very simple errors like spelling mistakes. In general, there was an imbalance in giving feedback on the four criteria.

Thu, the teaching assistant, added that the students' peer feedback was limited as it focused on isolating errors.

I realised that most of the students' feedback on the first drafts could not be used in my process of giving feedback. I usually recorrected many of the errors on the second drafts. Some students could locate errors but couldn't give any suggestions, especially about expression of ideas.

We can conclude that, notwithstanding the benefits of peer feedback, the students nonetheless expressed a distrust of their own and their peers' advice, most likely because of perceived or actual insufficient English language proficiency or English language knowledge. A number of suggestions to overcome such a potential obstacle to what has been considered to be an otherwise highly valued and beneficial experience in peer feedback will be provided next in the conclusion.

\section{Conclusion}

This study sought to show how a multiple-draft/multiple-party feedback approach (which encompassed peer/group feedback on the first drafts, teaching assistant feedback on the second drafts and lecturer feedback on the final drafts), aligned with the set of 10 principles that characterize AFL as proposed by the Assessment Reform Group (2002), and to understand the participating teachers' and students' perceived benefits of the approach. Using content analysis, interpretation of the data showed that the approach to feedback aligned with principles 1 to 9 and contributed to the tenth principle. Analysis also uncovered a process approach to writing in which students were given agency to improve their writing in collaborative, student-centred ways. The "three-pronged", multiple party feedback (Filipi, 2017) approach developed is an extension of the two-party feedback practice examined in previous research about multiple-draft feedback in English writing classes. It supports Bitchener and Ferris' (2012) recommendation about the need for and the usefulness of various instructors' feedback in L2 writing.

The findings about teachers and learners' perceptions about the multiple-draft/multiple-party feedback approach revealed that the strengths and benefits of the approach greatly outweighed the limitations. While the limitations identified are serious, they can nonetheless be overcome through attention to organization and careful training. To this end we propose following:

- First, the rotation of members' roles in group/peer feedback can occur every four weeks over the academic year instead of the same role throughout the semester. This means students will have opportunities to provide feedback in all of the four criteria in the checklist so that their knowledge about a wide range of linguistic elements will be then enhanced.

- Second, the grouping of students and the organisation of groups needs to be considered carefully. Each group should have at least one student with a high level of English proficiency who can assist the others as needed. As claimed by Pham (2013), groups of high- and low-achieving students could exert positive impacts on assessment as a group project.

- Third, there should be frequent training sessions to ensure peer feedback accuracy. The training sessions should be organized by writing instructors at least twice per writing semester. Explicit instructions about, and modelling of peer feedback for each of the criteria in the checklist, should be illustrated and worked through 
by instructors and students through interaction and in collaborative ways.

This qualitative case study is obviously limited by its small sample size. However, the aim was not to make generalizations based on the findings. Rather, through the detailed, "thick" description (Denzin, 1989) of the findings, the study extends the literature about teachers' and students' perceptions about feedback practices in general and the multiple-draft/multiple-party feedback approach in particular. Additionally, the study attempts to shed light on the potential of AFL for developing EFL university learners' writing skills through feedback practices that incorporate a student-centred component. The use of ten AFL principles (ARG, 2002) was particularly useful as a guide for analysing and understanding the practices around feedback and for implementing change in practice. Further research is needed to explore how multiple-draft/multiple-party feedback practices develop students' metacognition and self-regulation, an important aspect of AFL, and how the L1 and L2 are implicated in this work.

\section{Acknowledgments}

We are deeply indebted to the management board of the research site and all the participants, without whose voluntary participation the data collection for the research could not have been successfully carried out.

\section{References}

Assessment Reform Group. (2002). Assessment for learning: 10 principles. Retrieved from http://www.aaia.org.uk/afl/assessment-reform-group/?v=6cc98ba2045f

Bitchener, J., \& Ferris, D. R. (2012). Written corrective feedback in second language acquisition and writing. New York and London: Routledge.

Black, P., Harrison, C., Lee, C., Marshall, B., \& Wiliam, D. (2007). Assessment for learning: Putting it into practice. New York: McGraw-Hill Education.

Brookhart, S. M. (2008). How to give effective feedback to your students. Alexandria, VA: Association for Supervision and Curriculum Development.

Chandler, J. (2003). The efficacy of various kinds of error feedback for improvement in the accuracy and fluency of L2 student writing. Journal of Second Language Writing, 12, 267-296. https://doi.org/10.1016/S1060-3743(03)00038-9

Council of Europe. (2001). Common European Framework of Reference for Languages. Retrieved from https://www.coe.int/t/dg4/linguistic/source/framework_en.pdf

Denzin, N. K. (1989). The research act: A theoretical introduction to sociological methods. Englewood Cliffs, N.J.: Prentice Hall.

Ekşi, G. Y. (2012). Peer review versus teacher feedback in process writing: How effective? International Journal of Applied Educational Studies, 13(1), 33-48. Retrieved from http://www.academia.edu/5877495/Peer_Review_versus_Teacher_Feedback_in_Process_Writing_How_Eff ective

Evans, N. W., Hartshorn, K. J., \& Tuioti, E. A. (2010). Written corrective feedback: Practitioners' perspectives. International Journal of English Studies, 10(2), 47-77. https://doi.org/10.6018/ijes/2010/2/119191

Ferris, D. R. (2006). Does error feedback help student writers? New evidence on the short- and long-term effects of written error correction. In K. Hyland \& F. Hyland (Eds.), Feedback in second language writing: Contexts and Issues (pp. 81-104). Cambridge: Cambridge Univerisity Press. https://doi.org/10.1017/CBO9781139524742.007

Ferris, D. R. (2014). Responding to student writing: Teachers' philosophies and practices. Assessing Writing, 19, 6-23. https://doi.org/10.1016/j.asw.2013.09.004

Filipi, A. (2017). Blended learning, TESOL teacher preparation and quality assessment: Are they compatible? European Journal of Applied Linguistics and TEFL, 6(2), 189-212. Retrieved from http://link.galegroup.com/apps/doc/A519403989/AONE?u=monash\&sid=AONE\&xid=13cf48b7

Filipi, A. (2018). Teacher practices in establishing understanding in a foreign language classroom. Hacettepe University Journal of Education, Special Issue, 33, 36-53. https://doi.org/10.16986/HUJE.2018038795

Hyland, F. (2003). Focusing on form: Student engagement with teacher feedback. System, 31, $217-230$. https://doi.org/10.1016/S0346-251X(03)00021-6

Hyland, F. (2011). The language learning potential of form-focused feedback on writing. In R. M. Manchón (Ed.), Learning-to-write and writing-to-learn in an additional language. Amsterdam: Benjamins Publishing 
Company. https://doi.org/10.1075/1llt.31.12hyl

Hyland, K. (2003). Second Language Writing. Cambridge, UK; New York, N.Y.: Cambridge University Press. https://doi.org/10.1017/CBO9780511667251

Lee, I. (2008). Understanding teachers' written feedback practices in Hong Kong secondary classrooms. Journal of Second Language Writing, 17, 69-85. https://doi.org/10.1016/j.jslw.2007.10.001

Lee, I. (2011a). Bringing innovation to EFL writing through a focus on assessment for learning. Innovation in Language Learning and Teaching, 5(1), 19-33. https://doi.org/10.1080/17501229.2010.502232

Lee, I. (2011b). Feedback revolution: what gets in the way? ELT Journal, 65(1), 1-12. https://doi.org/10.1093/elt/ccpo28

Lee, I. (2011c). Formative assessment in EFL writing: An exploratory case study. Changing English: Studies in Culture and Education, 18(1), 99-111. https://doi.org/10.1080/1358684X.2011.543516

Lee, I. (2011d). Working smarter, not working harder: Revisiting teacher feedback in the L2 writing classroom. The Canadian Modern Language Review, 67(3), 377-399. https://doi.org/10.3138/cmlr.67.3.377

Lee, I. (2017). Classroom Writing Assessment and Feedback in L2 Contexts. Singapore: Routledge. https://doi.org/10.1007/978-981-10-3924-9

Leki, I. (2006). "You cannot ignore": L2 graduate students' response to discipline-based written feedback. In K. Hyland \& F. Hyland (Eds.), Feedback in second language writing: Contexts and Issues (pp. 266-285). Cambridge University Press. https://doi.org/10.1017/CBO9781139524742.016

Lichtman, M. (2014). Qualitative research for the social sciences. Thousand Oaks: SAGE Publications. https://doi.org/10.4135/9781544307756

Montgomery, J. L., \& Baker, W. (2007). Teacher-written feedback: Student perceptions, teacher self-assessment, and actual teacher performance. Journal of Second Language Writing, 16, 82-99. https://doi.org/doi:10.1016/j.jslw.2007.04.002

Nguyen, H. H. T. (2009). Teaching EFL writing in Vietnam: Problems and solutions-a discussion from the outlook of applied linguistics. VNU Journal of Science, Foreign Languages, 25, 61-66. Retrieved from http://repository.vnu.edu.vn/bitstream/VNU_123/57615/1/25.1.9.pdf

Nguyen, T. H. (2016a). Peer feedback practice in EFL tertiary writing classes. English Language Teaching, 9(6), 76-91. http://dx.doi.org/10.5539/elt.v9n6p76

Nguyen, T. H. (2016b). Feedback practices in English writing skills at tertiary level in Vietnam (Unpublished doctoral thesis). Monash University, Melbourne, Australia.

Nguyen, T. M. H., \& Hudson, P. (2010). Preservice EFL teachers' attitudes, needs, and experiences about teaching writing and learning to teach writing before their practicum: A case study in Vietnam. The Asian EFL Journal Quarterly, 12(2), 43-67. Retrieved from http://asian-efl-journal.com/PDF/June-2010.pdf

Patton, M. Q. (2002). Qualitative research \& evaluation methods (3rd ed.). California: Sage Publications.

Paulus, T. M. (1999). The effect of peer and teacher feedback on student writing. Journal of Second Language Writing, 8(3), 265-289. https://doi.org/10.1016/S1060-3743(99)80117-9

Pham, T. H. T. (2013). Using group projects as a strategy to increase cooperation among low- and high-achieving students. Higher Education Research \& Development, 32(6), 993-1006. https://doi.org/10.1080/07294360.2013.806436

Sato, M. (2013). Beliefs about peer interaction and peer corrective feedback: Efficacy of classroom intervention. Modern Language Journal, 97(3), 611-633. https://doi.org/10.1111/j.1540-4781.2013.12035.x

Storch, N., \& Aldosari, A. (2010). Learners' use of first language (Arabic) in pair work in an EFL class. Language Teaching Research, 14(4), 355-375. https://doi.org/10.1177/1362168810375362

Swaffield, S. (2008). Feedback: The central process in assessment for learning. In S. Swaffield (Ed.), Unlocking assessment: Understanding for reflection and application (pp. 57-72). London; New York: Routledge.

Tran, T. L. (2007). Learners' motivation and identity in the Vietnamese EFL writing classroom. English Teaching: Practice and Critique, 6(1), 151-163. Retrieved from https://files.eric.ed.gov/fulltext/EJ832183.pdf

Yang, M., Badger, R., \& Yu, Z. (2006). A comparative study of peer and teacher feedback in a Chinese EFL writing class. Journal of Second Language Writing, 15, 179-200. https://doi.org/10.1016/j.jslw.2006.09.004 
Yu, S., \& Lee, I. (2014). An analysis of Chinese EFL students' use of first and second language in peer feedback of L2 writing. System, 47, 28-38. https://doi.org/10.1016/j.system.2014.08.007.

Zhao, H. (2014). Investigating teacher-supported peer assessment for EFL writing. ELT Journal, 68(2), 155-168. https://doi.org/10.1093/elt/cct068

\section{Appendix A}

\section{Interview questions}

Interview with the student participants

1. How is your multiple-draft feedback practice implemented in your writing class?

2. What do you think about the multiple-draft feedback approach in your writing class? Does this feedback approach benefit you?

3. Are you satisfied or unsatisfied with each activity in this feedback approach? Please give your reasons.

4. Have you made any improvement in your writing with this feedback approach? Please give examples.

Interview with the teacher participants

1. How is your multiple-draft feedback practice implemented in your writing class?

2. What do you think about the multiple-draft feedback approach in your writing class? Does this feedback approach focus on the learners? Is it beneficial for you in providing feedback to student writing? Please give your opinions.

3. Are you satisfied or unsatisfied with each activity in this feedback approach? Please give your reasons.

4. Do you think that students' writing skills have been improved with this feedback approach? Please give examples. 


\section{Appendix B}

Samples of peer feedback, teaching assistant's feedback and lecturer's feedback A sample of peer/group feedback on one student's first draft

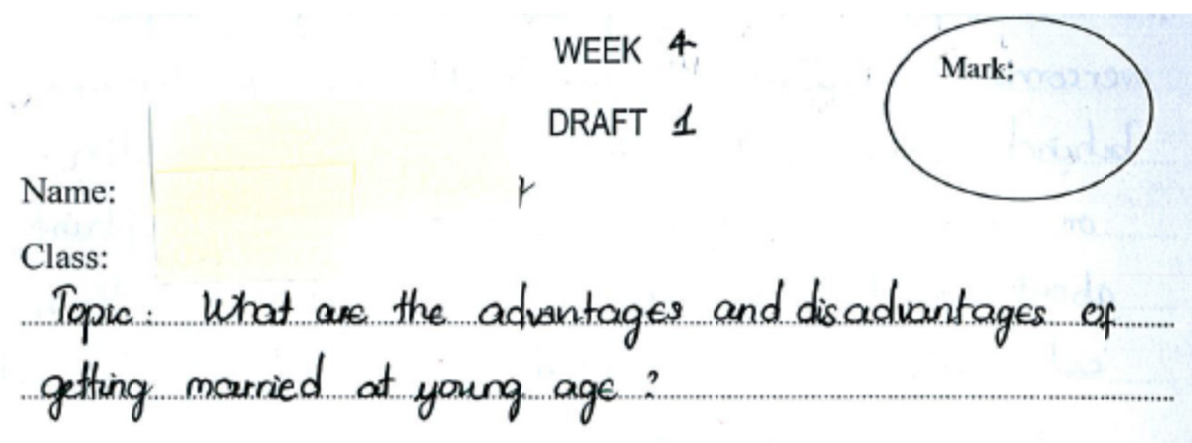

1 These days, people have many different paints of views about the age to get marriage for many people, findung Mr or Ms Right at the young age is a considerably -impartant choice. However, thene are both pros and ans.

5 to decide to do this. In this essay. I will cover both the benejits and challenges of this matter getting marnied early.

(To be gin with the upsides, ...the young marriage helps. ...couples more mature]. They aus going to haus more......

10 opportunities to experience real slcills in daily liye. Fot example, when you area single girl, you are... able to sleep lade in the morroing; however, . as you are mancied, you have to wake up earlier than... other members in your family to to prepare ..... the

is breakfast and do houseioporke. This makes you aware of . your dudy and responsibility in your family. leads you to work independently. 
Besides, getting mourried early may be an advantage.

At this age, the power of kve can help couples

20 overcome dijficulties and trouble in lige because. behind them there is always a motuation or a willing persom to listen any complaints about work or everything;; in addition to this, senthe turband or mife can shous and give uxegul

25. aduce for another

On the other hand, young cosuples can also face to a lot of downsides with their marriage. The first prob disadvantage is foursining problems. At the early age, they are trying to so setting up 30 career and difficultio is dear. They have to show their ability and prove it. to A As a result, They don't haus fime por each other and for faming. This can the break the relationship betwexn hurbaud and wife for misunderstanding together. 35 .. Moreover, finaunce is an rimportanto problem.... - Shortage of money can mate couples have traubles in doity lije and arrange dije. 
Student's name:

Checklist for group feedback (jigsaw feedback)

Group:

\begin{tabular}{|c|c|c|c|c|c|c|c|c|c|c|}
\hline \multirow{3}{*}{$\overline{-}$} & \multirow{2}{*}{ Checklist Questions } & \multicolumn{7}{|r|}{ Answers } & \multirow{2}{*}{ How to improve } & \\
\hline & & \multicolumn{5}{|c|}{ YES (with rating) ${ }^{*}$} & No & EXAMPLES & & \\
\hline & $\begin{array}{l}\text { 1. Does the essay provide all } \\
\text { relevant ideas to the topic given? }\end{array}$ & & & $\sqrt{ }$ & & & & $\begin{array}{l}\text { - To begin with the upoles : " } \\
\text { "On the other hand. dojonsides" }\end{array}$ & & \\
\hline \multirow{4}{*}{$\frac{n}{0}$} & $\begin{array}{l}\text { 2. Does the inuroduction clearly } \\
\text { introduce the topic and scope of } \\
\text { the essay? }\end{array}$ & & V & & & & & $\begin{array}{l}\text { 'Inthis essey, I will... the } \\
\text { becusyts and challengs..... }\end{array}$ & & \\
\hline & $\begin{array}{l}\text { 3. Does each paragraph in the } \\
\text { body contain only cne rain ides? }\end{array}$ & & & $\sqrt{ }$ & & & & -4 & & \\
\hline & $\begin{array}{l}\text { 4. Are supporting ideas in each } \\
\text { paragraph we!l-deve'oped wit.1 } \\
\text { strong arguments, evileace, } c \text { t } \\
\text { proof to persuade readers? }\end{array}$ & & & $\sqrt{ }$ & & & & & & $\cdot$ \\
\hline & $\begin{array}{l}\text { 5. Does the essay have an } \\
\text { effective conclusion which } \\
\text { summarises the ideas mantionax } \\
\text { in the introduction and or the } \\
\text { author's further comments or } \\
\text { suggestions for the topic given" }\end{array}$ & & & & & & & - lacking conchurim. & . & \\
\hline
\end{tabular}

Further comments (if any).

\section{Checklist for group feedback (jigsaw feedback)}

Student's neme:

Group:

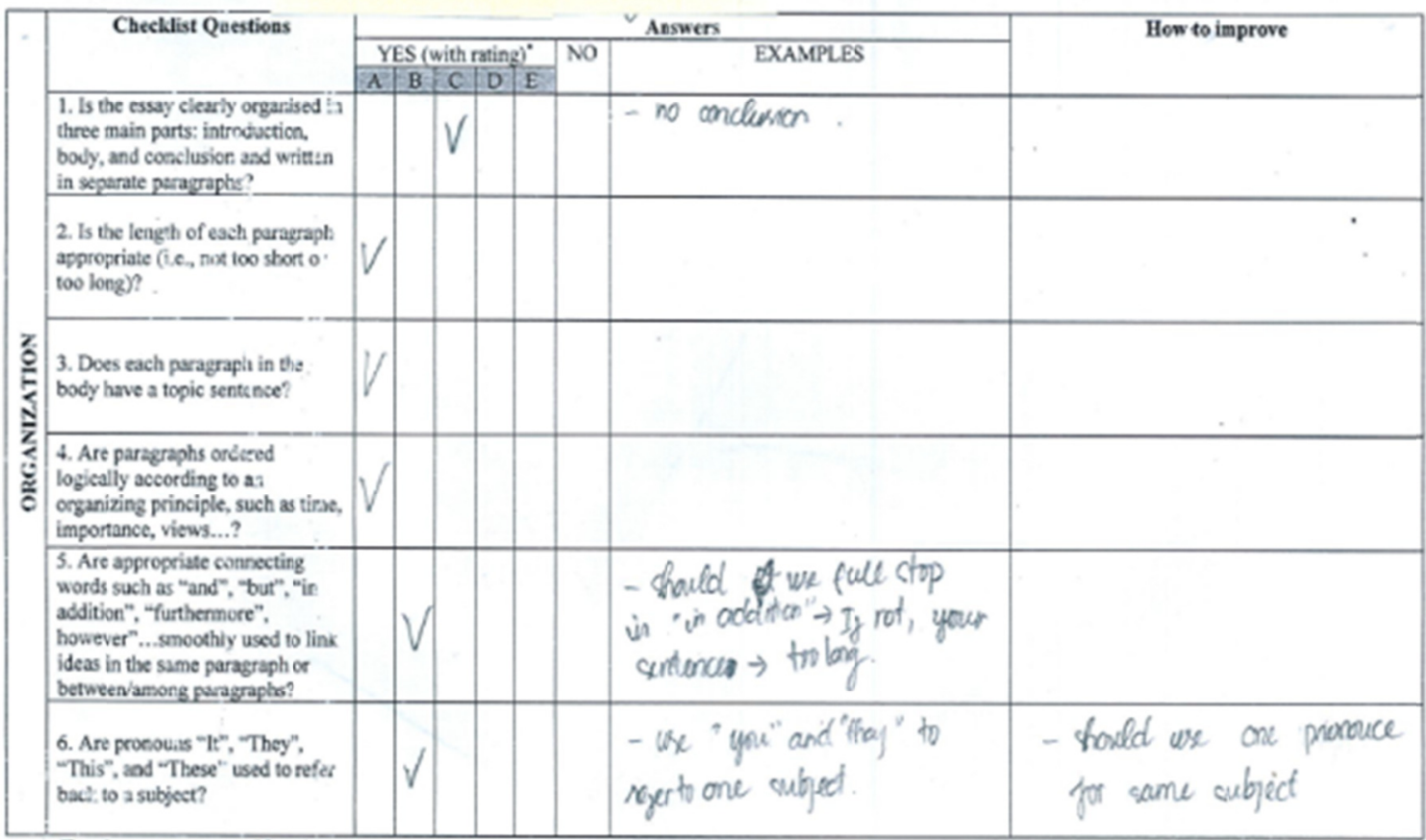

Further cosnments (if any): 


\section{Checklist for group feedback (jigsaw feedback)}

Student's name:

Group:

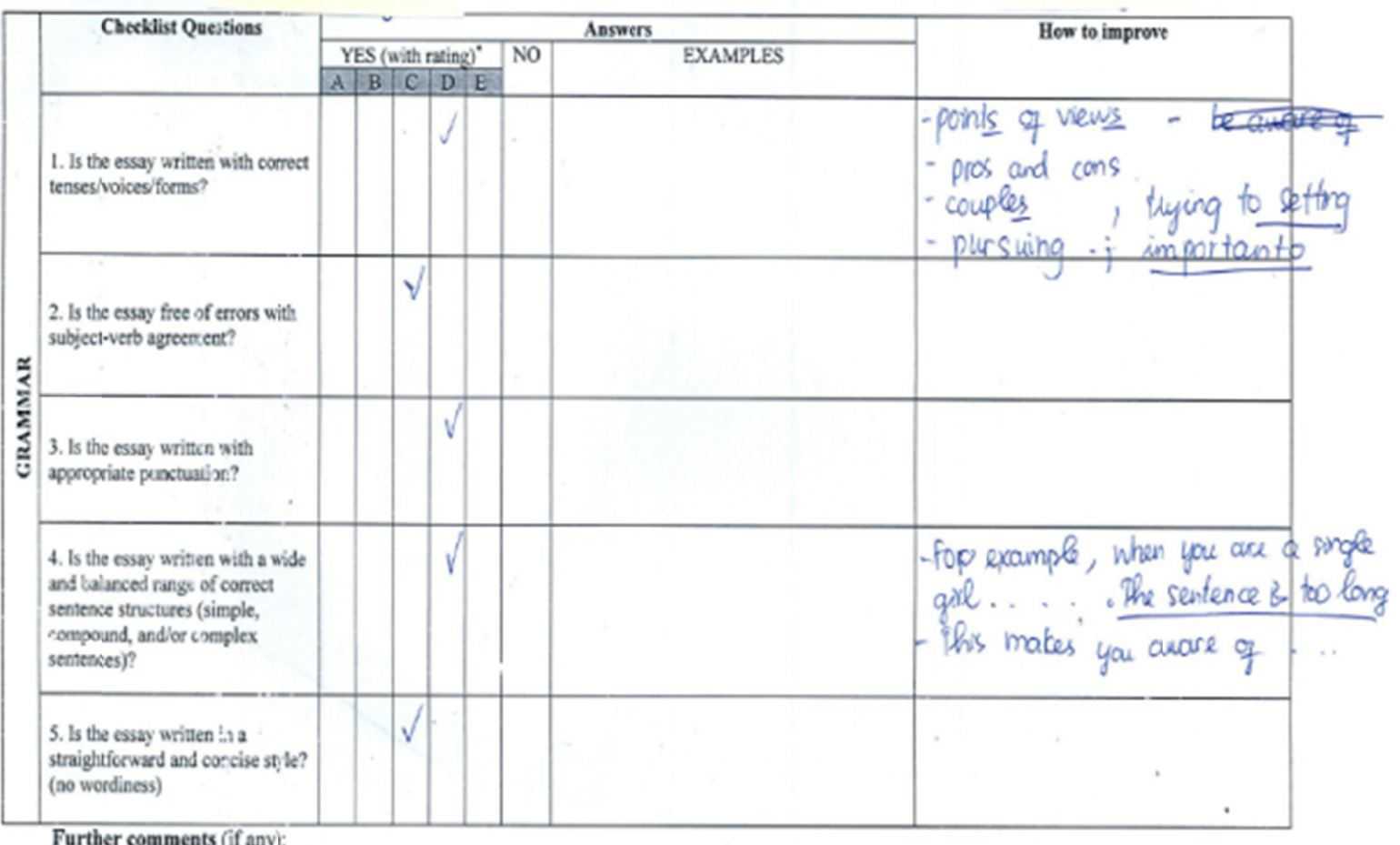

Checklist for group feedback (jigsaw feedback)

Student's name:

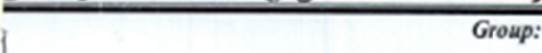

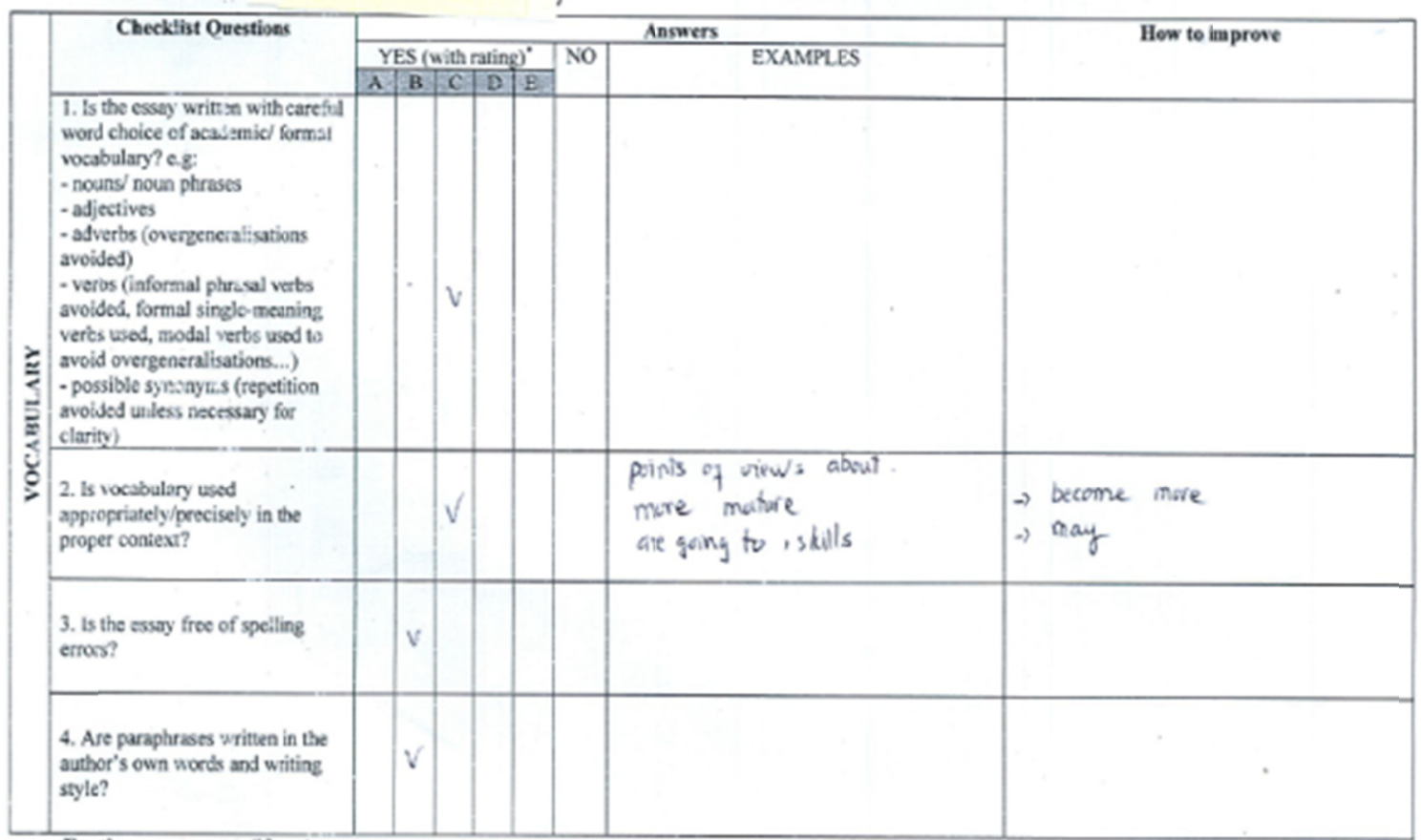

Further conamests (if any): 
A sample of the teaching assistant's written feedback on the student's second draft

\section{$\approx 360$ words}

DRAFT 2

1 ........These days....getting marrisd at young age is becoming inasessingly

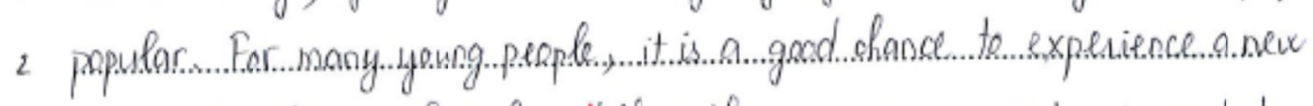

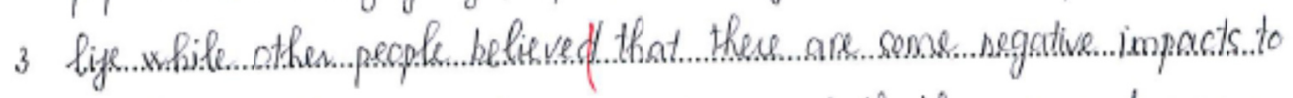

4 do this In this essay Tam going to coves both the pros and cons....

5 this...notten.

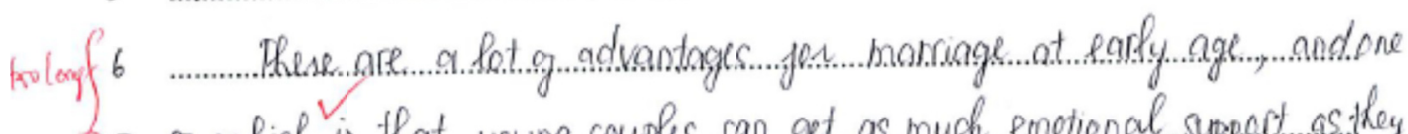

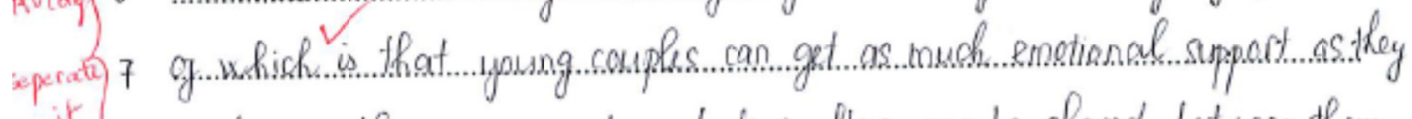

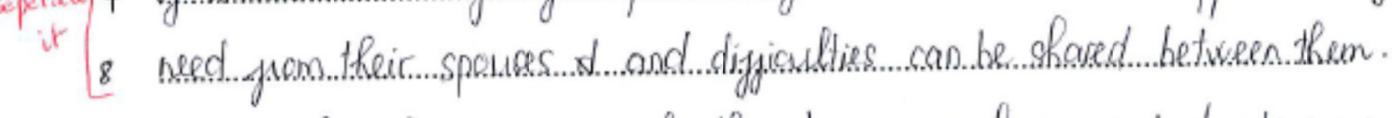

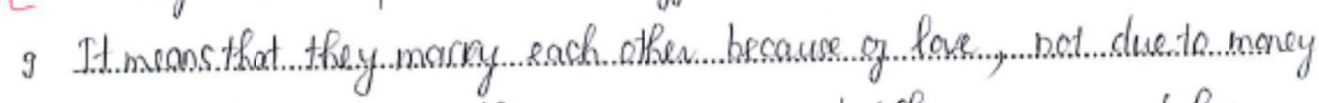

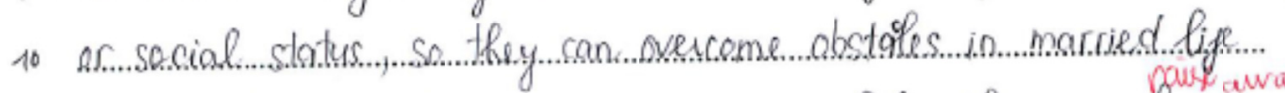

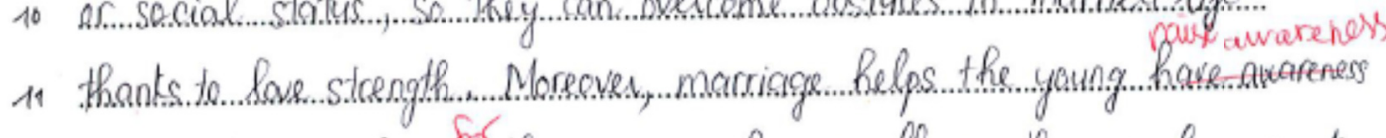

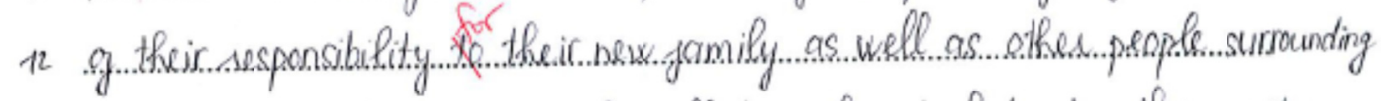

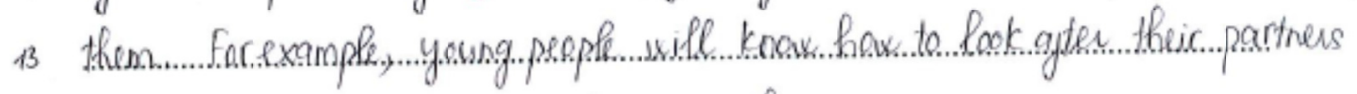

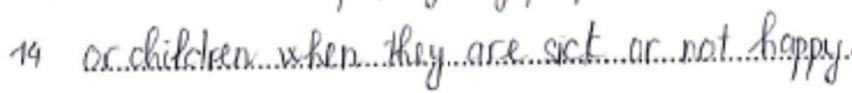

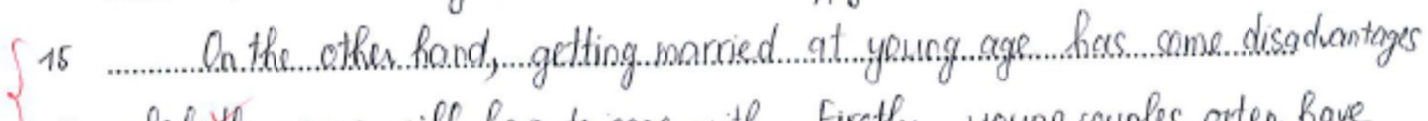

16 which the young will have to cope with firstly, woung rouphes ogten have

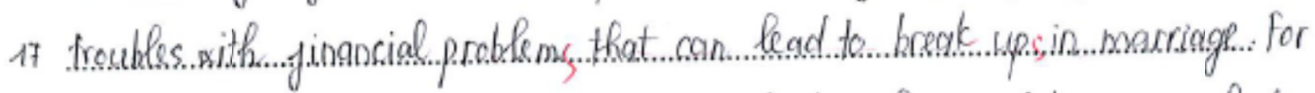

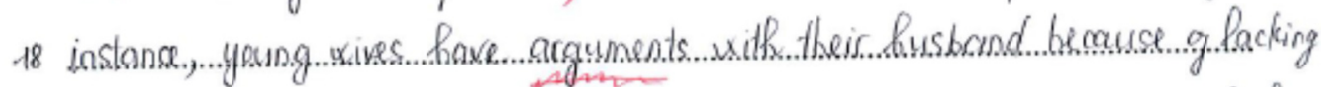

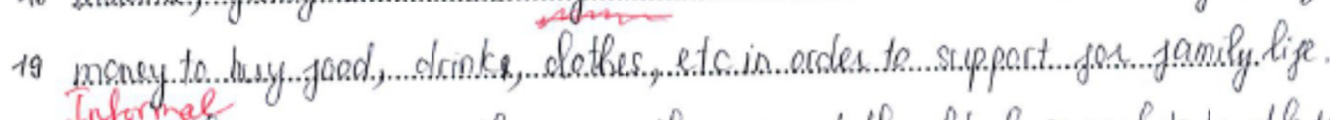

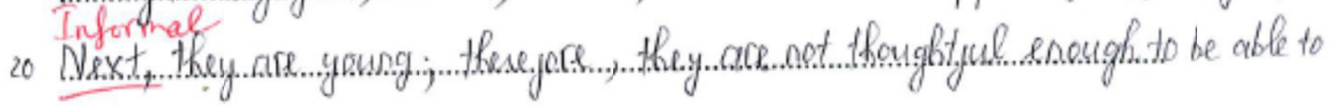


DRAFT

21 halance or olve issues in \& new ligh . They seem to ange immediately

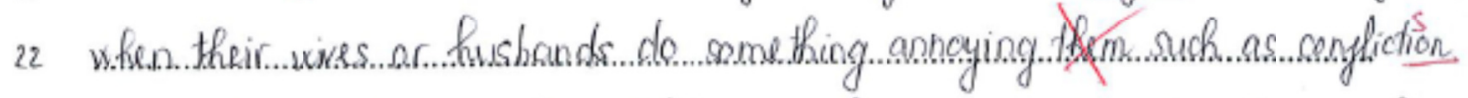

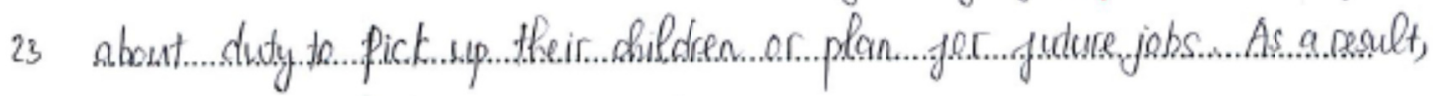

24 marrigge is split by minor mistakes

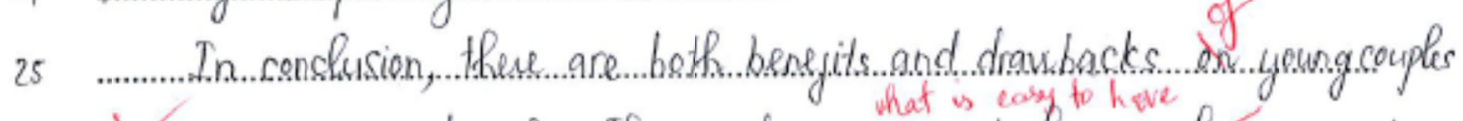

26 Int getting macried sarly.... The upsides are easy to have preling support

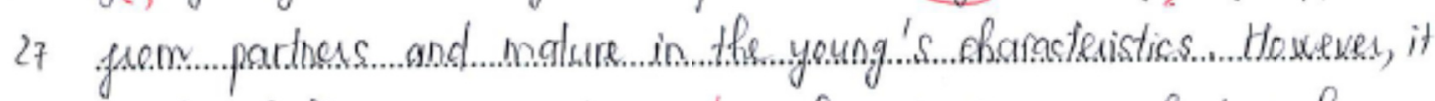

28 is also challanges jor enty - aged couples about....jinancial difjialtios

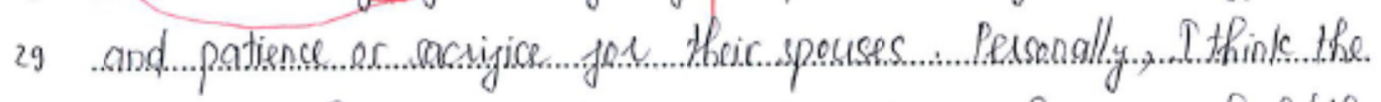

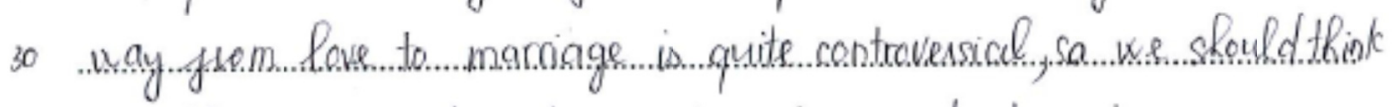

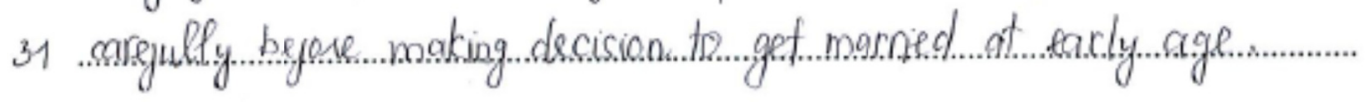


CHECKLIST FOR ACADEMIC ESSAY WRITING

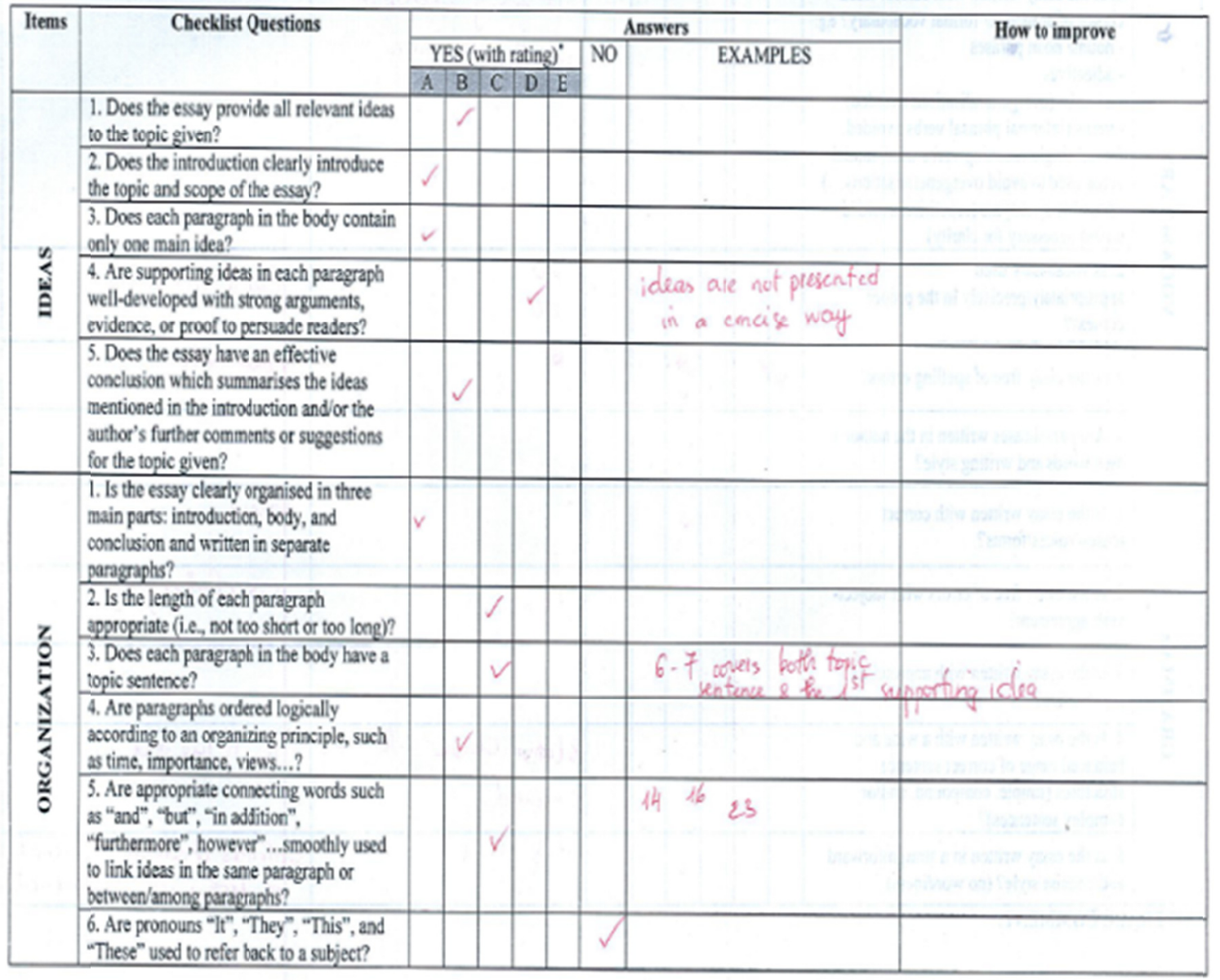

- A: excellent; 6: very good; C: good; D: fair; E: poor

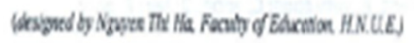




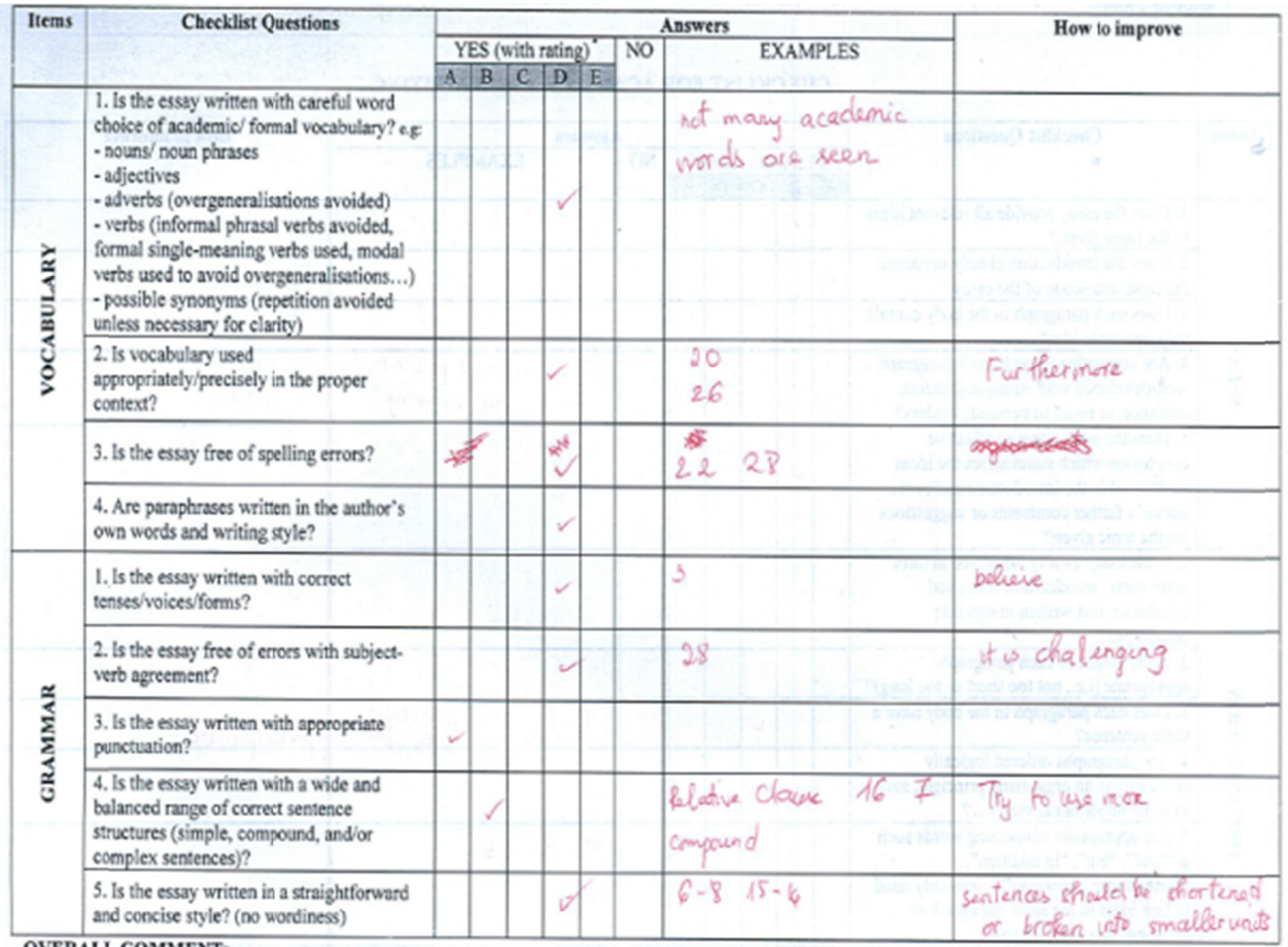

OVERALL COMMENT: 
A sample of the lecturer's feedback on the students' final draft

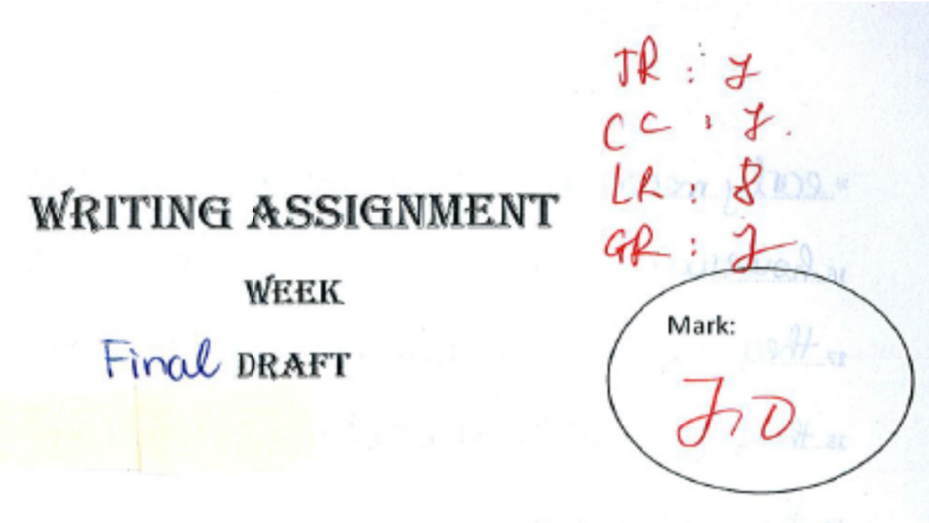

Class:

Name:

Topic: The advantages and disadantages of getting married at young - Getting married is one of the most important commitmants age.

2 made in life because it will lead to signijicant changes in 3. jeelings, social roles and responsibilities Howerver, the best age 4. to marry is still a contraversy and dijfers from others to of hers. 5. Some people bete believe that marrying at a young age has bas 6. negative ejgects, while others do not, Therejore, in this essay, I will 7 discuss some pros and cons og larly marriage

8. Furst gall, there are at least two benejits if people have wije 9. Or hushand ecurly, including happiness in life and 10. maturity in each indidual. Most people think the marriages of 11. young couples are usually jull gy love and romance as they have 12. not expected too much on their partners. As a result, they can

13.easily understand other's mistakes, support their lovers 14. Unconditionally and live more happily. Besides, setting of a jamily ৩ anid overgeneralization 
isearly means these caples should share and divide their duties,... 16. housework and mumerous dijferent issues in marriod life; hence, 17 they seem to be taught more about responsibilities for the ones 18 they love Gertainty, matherity and better liability are some reward 19. they can receive.

20. On the other hand, negative ingluences also exist alung with the 21.pasitive points mentioned financial concern is probably the biggest ${ }_{22}$ dis advantage. Yuunger people are jest starting oust, so their salarymay 23. nut be really good and not enough fo support family's needs such 24. as food, house, shot especially children Moreaver, the inexperienced "characteristic also cause some problems yor young jamilies. When 26. afetting ured early, peoplev seen to be fully aware of dif ficulties 27. happening in their jutere life, which will make the youeng un able to ${ }_{28}$ balance everything. These two drawbads are among the reasons why 29. the divorce rate oy young couples are recently increasing. ". In summary, early marriage obviously has both good and bad 31. sides as mentioned. If people want to en joy and maintain their 32. happy families, they had better deliberate thought fully 33. on when they are well-prepared enough to begin attach their. 34. lives with another. 


\section{Appendix C}

\section{A sample of the student's writing improvement}

The first draft

Topic: What are the advantages and dicadvantages of self-employment? 1........... These days, thene are wide ranges of jobf for people to choose

2. inducting self-emplcymentwhich is a common choice g vork. However, 3 is this positive, or are there more craubocks than advantages? In 4his essay, I will explore the pres and cons of self-employment andtry 5... to draw some condusions.

6.......... I will start by looking at the advantages. One og the major plus 7. proints g norking jor yoursely is juecdom about workingtime For instance, s. if you work in an gyice, timetable jou attending meetings is decided for a. you . This is not the case when you are bouss... secondly, sely-employment 10....means that you do not have to worry about other people's assessment, 11..so it aeduas stress be Por example, you have jue environment which 12 jexible time management jor both working and selaxing. 13....... On the other hand, this kind of job have some negative in pacts mon working productivity and personal habits. Obviously, you work or "......yourself; therejore you tonet tend to have less attempt or 16. competitive ability in working which locds to reduise working. 17...ineffectively. Moreover people dikely bring emotional.jussues into 18 work, and if they are theirown employe their plan g business 15......culd be ayfected in bad uay

"............ In condusion, these are both positives and negative to do 21 this way g jox warking personally, I believe it is inportant zing ger deciding you ou n job. 23. 
The final draft

Topic: What are the advantages and disadvantages g self-emplayment? ${ }^{1}$............. Most employees, at some peeirds of their careen, tend to have the 2...desire to be self-employed. Being you oun boss sounds really tempting; 3. however, is it positive, or ane there more drawbacks than advantages? 4. In this essay, I will explore the pros and cons g o self-employment and s...try to drax some conducions.

6........ I xill start by looking ot the advantages. One of the major plus points 7...g xorking jor youself is jueedom about time management. For instance, 8. if you work in an gyice, timetable for attending meetings is decided 9.jou you. This is not the case when you are you axn employes. 10. Morever, running you ou n business means that you do not need to take 11.permission jom anyone; theofore, these is no limit about vacation time. 12... Finally, ceff-operated business gives you opportunity to show your. OThe 13... skills. An Illustration is that not only do you have total contral over 14...yous whark but you cah also boost you confidence and potential ability. $\rightarrow$ are these skills? chat ability? unclear 
${ }^{15}$ On the other hand, working as an independent contractor has some. 16....estain ne gative impacts. Inifially, it takes more usponsibility than 17. working under others as you have to make you husiness plan and 18. Strategies alone. Success and yailture in work depend on you. Another 19. issue is that wark hous can be langer uith inconsistent income at the ${ }^{20}$ beginning gy huilding up reputation for business. Furthennore, employens 21.usually pay for heaffh insurance og their stays, but you will have 22.to pay you own one when you are sself-emplayed. 23.... In huief, these are both upsides and downsides in deciding to

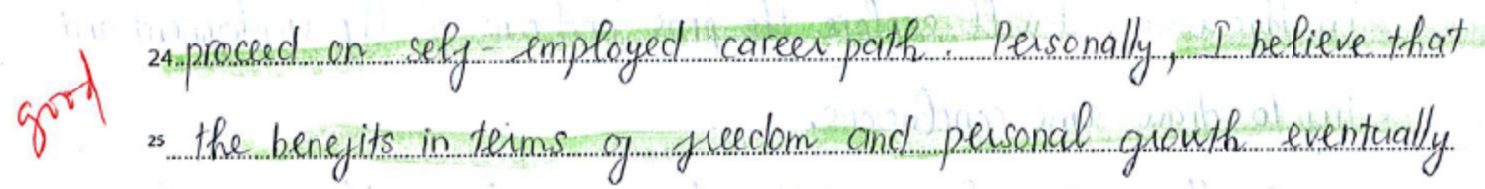
26...utweigh any hegatives.

27.

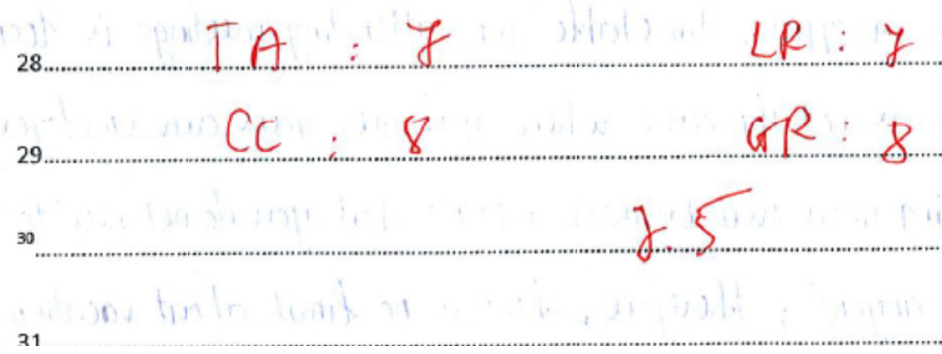

\section{Copyrights}

Copyright for this article is retained by the author(s), with first publication rights granted to the journal.

This is an open-access article distributed under the terms and conditions of the Creative Commons Attribution license (http://creativecommons.org/licenses/by/4.0/). 